\title{
Humanization of childbirth: meanings and perceptions of nurses
}

\author{
Humanização do parto: significados e percepções de enfermeiras \\ Humanización del parto: significados y percepciones de enfermeras
}

\author{
Andrêssa Batista Possati ${ }^{1}$ \\ Lisie Alende Prates ${ }^{1}$ \\ Luiza Cremonese $\mathrm{e}^{1}$ \\ Juliane Scarton ${ }^{2}$ \\ Camila Neumaier Alves $^{3}$ \\ Lúcia Beatriz Ressel ${ }^{1}$
}

1. Universidade Federal de Santa

Maria. Santa Maria, RS, Brasil.

2. Universidade Federal Rio Grande.

Rio Grande, RS, Brasil.

3. Universidade Federal de Pelotas.

Pelotas, RS, Brasil.
Corresponding author:

Lisie Alende Prates.

E-mail: lisiealende@hotmail.com

Submitted on 01/18/2017.

Accepted on 06/15/2017.

DOI: 10.1590/2177-9465-EAN-2016-0366

\begin{abstract}
Objective: To know the meanings attributed to humanized childbirth by nurses of an obstetric center. Method: A qualitative descriptive study was carried out with nurses from a teaching hospital, located in southern Brazil. An operational proposal was used. The participants were six nurses who worked in the service. Results: The humanization of childbirth was understood as a set of practices and attitudes based on dialogue, empathy and embracement; the provision of guidelines; the appreciation of parturients' singularities; the performance of procedures proven to be beneficial to maternal and child health and continuous professional updating. Conclusion: The humanization of birth is still a challenge in professional practice. The role of women, the respect for their rights and the commitment of health professionals are the foundation of the humanization of childbirth.
\end{abstract}

Keywords: Women's Health; Parturition; Humanizing Delivery; Humanization of Assistance; Nursing.

\section{Resumo}

Objetivo: Conhecer os significados atribuídos ao parto humanizado por enfermeiras de um centro obstétrico. Método: Pesquisa qualitativa descritiva, realizada com enfermeiras de um hospital de ensino, localizado no sul do Brasil. Utilizou-se a proposta operativa. Resultados: A humanização do parto foi compreendida como um conjunto de práticas e atitudes pautadas no diálogo, empatia e acolhimento; o fornecimento de orientações; a valorização da singularidade da parturiente; a realização de procedimentos comprovadamente benéficos à saúde materno-infantil e a constante atualização profissional. Conclusão: A humanização do parto ainda representa um desafio na prática profissional. O protagonismo da mulher, o respeito aos seus direitos e o comprometimento dos profissionais de saúde constituem os alicerces para a humanização do parto.

Palavras-chave: Saúde da Mulher; Parto; Parto Humanizado; Humanização da Assistência; Enfermagem.

\section{REsumen}

Objetivo: Conocer los significados atribuidos por enfermeras de un centro obstétrico al parto humanizado. Método: Investigación cualitativa, descriptiva, realizada con enfermeras de hospital de enseñanza del Sur de Brasil. Se utilizó la propuesta operativa. Resultados: La humanización del parto fue comprendida como un conjunto de prácticas y actitudes pautadas en el diálogo, empatía y acogimiento; en brindar orientaciones; en valorar la singularidad de la parturienta; en realizar procedimientos de comprobado beneficio para la salud materno-infantil; y en la constante actualización profesional. Conclusión: La humanización del parto representa aún un desafío en la práctica profesional. El protagonismo de la mujer, el respeto por sus derechos y el compromiso de los profesionales de salud constituyen los fundamentos de la humanización del parto.

Palabras clave: Salud de la Mujer; Parto; Parto Humanizado; Humanización de la atención; Enfermería. 


\section{INTRODUCTION}

Midwifery has gone through countless changes over time. At the end of the $20^{\text {th }}$ century, women used to give birth with the help of midwives at home. ${ }^{1}$ The presence of physicians was only requested when there was a complication during labor.

New practices have been gradually introduced in the process of parturition, thus making it medicalized. After the Second World War and with technical and scientific progress and the evolution of medicine, pregnancy and birth became hospital events, in which technological and surgical means were used. ${ }^{1}$ At that time, the Church and the State also began to care about questions related to people's health. ${ }^{2}$

After these changes, the increase of interventions during the pregnant-postpartum cycle and the excessive medicalization contributed to a new parturition setting, in which women are submitted to unnecessary procedures and their anatomy is no longer respected. Consequently, health professionals were increasingly prominent by performing these procedures and became the main characters of this event. ${ }^{3}$

Moreover, women began to be hospitalized earlier. Once at the hospital, they are provided with little information about the procedures they will be undergoing and they remain alone during labor, with little privacy. ${ }^{4}$

It is now known that these interventions and conducts may worsen care provided to women during childbirth, as their rights and of their families are ignored in this process. In view of this, the World Health Organization (WHO) has proposed some changes, as well as the Brazilian Ministry of Health and some NGOs. These changes are focused on care provided to women, including the return of natural childbirth. They have also encouraged the participation of nurse-midwives and teams qualified in the assistance of pregnancy and childbirth, in addition to incentive initiatives so that childbirth can be regarded as a physiological process conducted from a humanizing approach. ${ }^{5}$

Humanized care of childbirth refers to the need of a new approach that understands it as a truly human experience. Receiving, listening, providing guidance and creating bonds are essential aspects of care of women in this context. ${ }^{6}$

The concept of humanization in this study includes actions, practices, behaviors and knowledge based on the healthy development of labor and childbirth processes, with the respect of individuality and valuation of women. ${ }^{7}$ The concept of humanization was adopted as per the recommendations of the Brazilian Program for Humanization of Prenatal and Childbirth Care (PHPN, as per its acronym in Portuguese), created in 2000 with the purpose of qualifying prenatal care with regard to access and coverage, but also to improve parturition processes. ${ }^{8}$

According to the PHPN, humanization encompasses a decent reception of the women-baby-family triad, on the basis of ethical and supportive conducts. To do so, the institution must be well organized with an embracing environment, where practices that break with the traditional isolation of women prevail. It also encompasses the inclusion of practices and procedures that contribute to monitoring of childbirth, leaving behind impersonal and interventionist conducts that may put women and children's health at risk. ${ }^{8}$

The PHPN has brought many recommendations for clinical practice and therapeutic approaches on the basis of scientific evidence, such as the participation of an accompanying person at the woman's discretion, the qualification of personal relationships among professionals and parturients, the creation of spaces for knowledge building and information, greater participation, autonomy and decision power over their body, among others. ${ }^{9}$ The humanization of care is essential to make sure that a unique moment like childbirth is experienced in a positive and enriching way. In that sense, this study was guided by the following question: "What is the meaning attributed to humanized childbirth by nurses of an obstetric center?"

\section{METHOD}

This is a field study with a qualitative and descriptive approach. The study setting was the obstetric center (OC) of a teaching hospital in southern Brazil. It is worth mentioning that this is a reference hospital of the Brazilian Unified Health System (SUS, as per its acronym in Portuguese) which serves 42 municipalities in the region.

The participants were six nurses who worked in the $\mathrm{OC}$ of the aforementioned hospital. At the time, eight nurses worked there. The participating nurses worked in different shifts. The inclusion criteria were: nurses who had an undergraduate degree in nursing and who worked at the hospital's OC. As for the exclusion criteria, nurses who were on sick leave or on vacation during data collection did not participate in the study.

Data were collected in September 2015 by means of semistructured interviews. The meaning of the term "humanization" was questioned, as well as the general aspects of the topic that nurses considered to be important. Interviews lasted about 20 to 25 minutes and were ended after data saturation, that is, when the objective was achieved, and repetition of data was assessed. ${ }^{10}$

The semi-structured interview allowed interviewees to argue about the study object, without being fixed to questions, answers or conditions determined by the researcher. It was proven to be an effective instrument of data collection, since it allowed for an accurate representation of the group of nurses and thus highlighted their values, rules and references. ${ }^{10}$

The interviews were recorded with previous authorization and were then transcribed in order to be analyzed and interpreted. Worthy of note that we proposed to carry out the interviews in another place and another time. However, due to their availability and to respect the place they chose, data collection was done at the workplace, since they believed this would not affect their duties.

The operative proposal was used as a method for data analysis, being divided into two operational levels: exploratory and interpretative. ${ }^{10}$ The first operational level includes the knowledge of the social-historical context of the group studied. As for the second operational level, defined as interpretative, 
it consisted of empirical facts, with the purpose of searching an internal logic, projections and interpretations of participants' statements.

This phase was divided into two steps, which were the sorting and classification of data. It included the time when participants' speeches were transcribed and organized, resulting in a horizontal map of findings during the field work; and data classification, which consisted of the process of knowledge construction in a more complex way, covering the following steps: horizontal and exhaustive reading of texts, after which the empirical categories were created; transversal reading, after which the material was divided into topics, categories or meaningful units, and convergence of similar elements; final analysis, which included the analysis of the empirical material based on the theoretical framework; and final report, which consisted of the summary and presentation of the study results.

The whole study was conducted under ethical principles, in compliance with legal regulations of Resolution 466/2012. ${ }^{11}$ The research project was approved by the institution's research ethics committee. A free and informed consent form was provided to participants. Two copies of the document were printed, one of which remained with participants and the other with the researchers. In order to ensure anonymity, an alphanumeric system was used for nurses' speeches, with the letter $\mathrm{N}$ followed by a number (e.g., N1, N2, N3, etc.), according to the sequence of interviews.

\section{RESULTS AND DISCUSSION}

Nurses were aged between 24 and 32 years old. They completed their undergraduate studied between 1994 and 2013. One of them completed a specialization course in midwifery and pediatric nursing, two were specialized in midwifery nursing, one did multiprofessional residency in maternal-child health, and two were carrying out a multiprofessional residency in that field.

As for their marital status, two were married, two were single and two were in unmarried unions. The length of professional experience ranged between one month and 18 years. Thus, on the basis of the collected material, the meaningful core that arose was "The humanization of childbirth: unveiling meanings and care practices among nurses".

\section{Humanization of childbirth: unveiling meanings among nurses}

It is assumed that when the first contact of parturients with health services is based on actions focused on embracement and meeting health needs, it contributes to a humanized and qualified care service. Clarification about the routine and procedures to be performed also helps to ensure that childbirth is experienced peacefully and trustingly by women.

Therefore, when humanization of childbirth is conceptualized, it can be understood as a trend based on women's individuality and singularity that values their prominence and allows for greater consistency of care with their system of beliefs and values. ${ }^{7,8}$ This can be observed in the statements below:
Humanization of childbirth is a set of conducts, behaviors and attitudes that begin with the reception of patients, talking to them when they get in the hospital, the way we approach them (N2).

It is a comprehensive reception, from the hospital doors, by the medical and nursing staffs, of patients and people accompanying them. The provision of guidance, of what will be done with them, the whole labor process, everything with previous guidance, explanation (N3).

As observed, reception and information provided were considered by nurses as a means to humanize childbirth. In addition, these measures are important for the care provided, not only for women who come to the health service, but also for the accompanying family.

Reception includes an appropriate time for the healthcare staff to show their concern, interest and availability by getting to know and understand the parturient and her family's expectations, and clearing doubts related to pregnancy and delivery. Reception tends to make the relationship between parturients and professionals easier, consequently avoiding stressful situations and anguish for women and their families. ${ }^{12}$

Besides the reception mentioned by the nurses, these interviews show an encouragement to free walking, standing, expression of feelings and expectations, and the active participation of women in the delivery process.

Nonpharmacological techniques for pain relief, such as free walking and standing, in interviewees' opinion, are practices that should be performed in order to improve the care provided and make it humanized.

Humanization of childbirth takes place when you know the pregnant woman's expectations, when you allow them to express themselves, to scream if they think it is going to relieve. She can choose her position and not be stuck on the bed (N1).

It is to know how she wants the delivery to be, if she wants to give birth sitting or in another way, she has to choose, it is not up to us, as professionals, to decide on that (N5).

It is understood, based on the participants' speeches, that the use of techniques to relieve pain and active participation of the pregnant woman are practices related to humanization of childbirth. These practices tend to help parturients to have more freedom and autonomy. Some authors ${ }^{13}$ confirm the findings of this study since they found that nurses also emphasize the importance of women having autonomy to move freely during labor. This practice is considered to favor fetus development while respecting women's physical features and providing greater comfort.

Despite the evidence, it is also known that in many maternity hospitals women are still asked to remain in bed in left lateral decubitus during labor. Although this position contributes to 
the uteroplacental and kidney blood flow, women must be encouraged to remain in the position they wish. It is noteworthy that walking, as well as other positions, does not pose any obstetric risk and actually contributes to shorten the labor process and reduces the need for sedation. ${ }^{13}$

The nurses who participated in this study also believe that humanization of childbirth means women-centered care, and the replacement of interventionist practices by less invasive ones, focusing care on more humanized conducts.

\section{It is not to perform unnecessary procedures, iatrogenesis (N3).}

Not to perform unnecessary invasive procedures, such as episiotomy, enema, trichotomy, successive vaginal examinations and more than one person examining the woman several times (N1).

It is possible to notice in the statements above that respect of women's role consists of an attitude that is interwoven in the process of humanization of childbirth. To do so, avoiding practices and procedures currently considered to be invasive or no longer adequate is essential.

Care based on interventions and use of invasive procedures and technologies may result in women playing only a secondary role and shifting the leading role to health professionals. This situation results in an increase of maternal mortality ratio and contributes to the disrespect of reproductive rights. ${ }^{3}$

The practices and techniques referred to in participants' statements include trichotomy, enema, labor induction, and medicalization. Routine enema is still very common in many maternity hospitals and it is used to reduce the length of labor and the risk of perineal area contamination. ${ }^{14}$ However, the literature suggests that there is no scientific evidence of enema effectiveness, as a systematic literature review proved that the performance of this procedure does not contribute to reduce puerperal and neonatal infection. ${ }^{15}$

Regarding trichotomy, which is another common procedure in health services, it is performed with the aim to reduce infection and make stitching easier, when episiotomy is necessary or in case of laceration. However, it is also known that its daily use can increase the risk of infection by diseases such as HIV (human immunodeficiency virus) and hepatitis. ${ }^{14}$ Therefore, some interventionist practices and procedures are not recommended and have no scientific basis to be used within institutions.

From the interviewees' perspective, humanization of childbirth requires a new attitude from professionals. This attitude concerns the relationship between professionals and patients, empathy, sensitivity, and respect to individuality. The statements below show how important empathy and respect are to care services and humanized practices.

It is empathy, when you put yourself in someone else's position. To think about what you would have wanted, to know what is important to her, what her feeling is, to know she has a name, an identity, not mommy or daddy (N4).

We have to actually put ourselves in their place. How would we like to be treated at that moment? This is the most important thing, because we are so stuck to the routine and we end up not putting ourselves in their place and doing things automatically (N1).

According to the nurses' statements, empathy and respect are directly related to the way people are treated, approached, how doubts are cleared or simply to listening to their needs and understanding the demands brought to the service. Thus, it is understood that humanization appears as an attempt to reinforce the principles of comprehensiveness, equity and accessibility recommended by the SUS.

The authors' findings ${ }^{16}$ confirm those speeches since they state that acts of empathy, sensitivity and respect reflect positively on the problem-solving characteristic of health services and on the fulfillment of patients' demands. In that sense, the definitions presented by the interviewees are also based on public policies and recommendations of the Ministry of Health, which recover the humanization of childbirth and SUS principles. ${ }^{14}$

Authors highlight that humanizing birth care implies a change of attitude and conduct, by means of a care service that ensures respect and sensitivity with the woman-child-family triad. Humanization must go beyond the good treatment of people and include appreciation of subjects and respect of their singularities.

After the analysis of nurses' speeches, it is considered that humanizing childbirth includes the revision of actions and conducts of health professionals. As a consequence, it is also believed that training and permanent updating of both professionals and institution managers are essential to implement humanized practices, and this is endorsed in the statement below:

I believe it begins with professional training, with professionals being permanently updated to understand the most adequate and necessary practices more easily. Professionals who do not seek updating and do not follow these new recommendations by the Ministry of Health are more limited to older practices. As for the institution's manager, it is also important to encourage professionals and work together with the team. Team meetings are also important to discuss and see how the routine is going (N3).

This statement shows the importance of professional updating concerning care of pregnant women. The holding of staff meetings and the discussion of daily practices in the services also appears in this context as a tool to be used every day by these professionals.

Training of health professionals has been discussed in studies related to humanization of childbirth. As an example, we 
can mention medical training in obstetrics, which has pointed out flaws regarding the humanization of care. Medical conducts are still based mostly on unnecessary interventions, while midwife nursing training shows distinct and humanized conducts that respect childbirth physiology. ${ }^{5,17,18}$ Therefore, it is necessary to include the topic of humanization in institutional training programs and in continuing education actions in health, as well as in professional training as a common thread to enhance it. ${ }^{19}$ The inclusion of this topic represents a strategy that may help to introduce a new birth care model based on humanized practices.

\section{CONCLUSIONS}

Humanization of childbirth, recognized as a public health policy, was understood by interviewed nurses as a set of conducts, behaviors and attitudes, free of judgment and based on dialogue, empathy and embracement of patients and their families; the provision of guidance and information about conducts to be adopted; the appreciation of the parturient and their personification as subjects with rights and needs. For interviewees, humanization of childbirth also involves the performance of procedures proven to be beneficial to maternal-child health, and abandoning unnecessary and invasive techniques such as episiotomy, enema, trichotomy and successive vaginal examinations; and the continuous professional updating implemented in staff meetings, based on current scientific evidence and encouraged by the institution's managers.

In this process, humanization implies the respect of choices, individualities and singularities of each parturient. Nurses are aware of policies and recommendations of the Ministry of Health and WHO, and they believe the process of humanization is slow and full of challenges.

Nurses' statements showed the importance of empowering patients and considering childbirth as a natural and physiological event again. In this event, women are assisted by a health professional, according to their needs, and they can actively participate and have their rights ensured as a woman and as a patient.

To understand the meaning of humanization of childbirth and its positive implications in women's lives is to be oriented towards the care of patients. In that sense, health professionals must give a voice to parturients in the first place, listen to their complaints, desires, doubts and expectations and then outline the necessary changes for a humanized childbirth. Otherwise, settings characterized by a precarious physical infrastructure will prevail, in which professionals are focused on techniques and interventions and guided by medicalizing norms and routines that disrespect women's rights.

The authors believe this study may unveil the meaning of humanized childbirth, as it is understood by nurses who participated in its development. As implications of this study, the authors believe it can support other health professionals and encourage managers to make the necessary changes in the childbirth setting and promote its humanization.
This study can also give way to reflections about care provided to parturients in an attempt to find a way of caring that contributes to their prominence. This study is also expected to help health teams, not only nurses, in the assessment of their professional practice, and allow for reflections about the importance of appreciating each individual's singularity in this event, in addition to the implementation of strategies for humanization of care of parturients and their families.

However, it is important to consider that this study was carried out with nurses of a specific obstetrics institution and setting, which may be a limitation if results are mainstreamed. In addition, the length of professional experience in the field of women's health may have been a limitation as well. Nevertheless, participants accounted for nearly all nurses working in the service.

Therefore, further studies must be carried out in other institutions, with a larger number of health professionals, from different categories, as well as nurses, like it was done in this study. Knowing and understanding other contexts can be relevant, since each institution and each health professional can give a different meaning to the topic.

\section{REFERENCES}

1. Leister N, Riesco MLG. Assistência ao parto: história oral de mulheres que deram à luz nas décadas de 1940 a 1980. Texto Contexto Enferm [Internet]. 2013; [cited 2017 Mar 17];22(1):166-74. Available from: http:// www.scielo.br/pdf/tce/v22n1/pt_20.pdf

2. Mattar LD, Diniz CSG. Hierarquias reprodutivas: maternidade e desigualdades no exercício de direitos humanos pelas mulheres. Interface (Botucatu) [Internet]. 2012; [cited 2017 Mar 17]; 16(40):107-20. Available from: http://www.scielosp.org/pdf/icse/v16n40/aop0212.pdf

3. Pinheiro BC, Bittar CML. Percepções, expectativas e conhecimentos sobre o parto normal: relatos de experiência de parturientes e dos profissionais de saúde. Aletheia [Internet]. 2012; [cited 2017 Mar 17] (37):212-27. Available from: http://pepsic.bvsalud.org/pdf/aletheia/n37/ n37a15.pdf

4. Carvalho VF, Kerber NPC, Azambuja EP, Bueno FF, Silveira RS Barros AM. Direitos das parturientes: conhecimento da adolescente e acompanhante. Saúde Soc [Internet]. 2014; [cited 2017 Mar 17] 23(2):572-81. Available from: http://www.scielo.br/pdf/sausoc/ v23n2/0104-1290-sausoc-23-2-0572.pdf

5. Narchi NZ, Cruz EF, Gonçalves R. O papel das obstetrizes e enfermeiras obstetras na promoção da maternidade segura no Brasil. Ciênc Saúde Coletiva [Internet]. 2013; [cited 2017 Mar 17]; 18(4):1059-68. Available from: http://www.scielosp.org/pdf/csc/v18n4/19.pdf

6. Koettker JG, Brüggemann OM, Dufloth RM. Planned home births assisted by nurse midwives: maternal and neonatal transfers. Rev Esc Enferm USP [Internet]. 2013 Out; [cited 2016 Ago 3]; 47(1):15-21. Available from: http://www.scielo.br/pdf/reeusp/v47n1/en_a02v47n1. pdf

7. Casate JC, Corrêa AK. Humanização do atendimento em saúde: conhecimento veiculado na literatura brasileira de enfermagem. Rev Latino-Am Enfermagem [Internet]. 2005; [cited 2017 Mar 17]; 13(1):105 11. Available from: http://www.scielo.br/pdf/rlae/v13n1/v13n1a17.pdf

8. Ministério da Saúde (BR). Programa Humanização do Parto: Humanização no Pré-natal e nascimento. Brasília (DF): Ministério da Saúde; 2002

9. Velho MB, Santos EKA, Brüggemann OM, Camargo BV. Vivência do parto normal ou cesáreo: revisão integrativa sobre a percepção de mulheres. Texto Contexto Enferm [Internet]. 2012 abr/jun; [cited 2016 Jul 4];21(2):458-66. Available from: http://www.scielo.br/pdf/tce/v21n2/ a26v21n2.pdf 
10. Minayo MCS. O desafio do conhecimento: pesquisa qualitativa em saúde. 14ª ed. São Paulo: Hucitec; 2014.

11. Ministério da Saúde (BR). Resolução № 466, de 12 de dezembro de 2012: diretrizes e normas regulamentadoras de pesquisa envolvendo seres humanos. Brasília (DF): Ministério da Saúde; 2012.

12. Santos LM, Pereira SSC. Vivências de mulheres sobre a assistência recebida no processo parturitivo. Physis (Rio J) [Internet]. 2012; [cited 2016 Jul 12]; 22(1):77-97. Available from: http://www.scielo.br/pdf/ physis/v22n1/v22n1a05.pdf

13. Silva DAO, Ramos MG, Jordão VRV, Silva RAR, Carvalho JBL, Costa $M M N$. Use of non-pharmacological methods for providing pain relief during the natural childbirth: integrative review. J Nurs UFPE On Line [Internet]. 2013; [cited 2017 Mar 18]; 7(esp):4161-70. Available from: http://www.revista.ufpe.br/revistaenfermagem/index.php/revista/article/ view/2582/pdf_2607

14. Ministério da Saúde (BR). Cadernos HumanizaSUS. Humanização do parto e do nascimento. Brasília (DF): Ministério da Saúde; 2014.

15. Reveiz L, Gaitán HG, Cuervo LG. Enemas during labour. Cochrane Database of Systematic Reviews [Internet]. 2013; [cited 2016 Jul 9];7. Available from: http://onlinelibrary.wiley.com/doi/10.1002/14651858. CD000330.pub4/full
16. Oliveira Junior JC, Souza MKB. A humanização nos serviços da atenção básica de saúde: concepções de profissionais de saúde. Rev Enferm UFPE On Line [Internet]. 2013 jun; [cited 2016 Jun 10]; 7(5):4370-7. Available from: http://www.revista.ufpe.br/revistaenfermagem/index. $\mathrm{php} / \mathrm{revista/article/download/3378/6384}$

17. Sousa AMM, Souza KV, Rezende EM, Martins EF, Campos D, Lansky S. Práticas na assistência ao parto em maternidades com inserção de enfermeiras obstétricas, em Belo Horizonte, Minas Gerais. Esc Anna Nery [Internet]. 2016; [cited 2017 Mar 16]; 20(2):324-31. Available from: http://www.scielo.br/pdf/ean/v20n2/1414-8145-ean-20-02-0324.pdf

18. Caus ECM, Santos EKA, Nassif AA, Monticelli M. O processo de parir assistido pela enfermeira obstétrica no contexto hospitalar: significados para as parturientes. Esc Anna Nery [Internet]. 2012 Mar; [cited 2017 Mar 16]; 16(1):34-40. Available from: http://www.scielo.br/pdf/ean/ v16n1/v16n1a05.pdf

19. Medeiros LMOP, Batista SHSS. Humanização na formação e no trabalho em saúde: uma análise da literatura. Trab educ saúde [Internet] 2016 [cited 2017 Mar 16];14(3):925-51. Available from: http://www. scielo.br/pdf/tes/v14n3/1678-1007-tes-14-03-0925.pdf 